\title{
Antropologinen lingvistiikka
}

\section{Gruzdeva, Ekaterina}

Suomalaisen Kirjallisuuden Seura

2020

Gruzdeva , E \& Janhunen , J 2020 , Antropologinen lingvistiikka . julkaisussa M Luodonpää-Manni , M Hamunen , R Konstenius , M Miestamo , U Nikanne \& K Sinnemäki (toim), Kielentutkimuksen menetelmiä I-IV . Suomalaisen Kirjallisuuden Seuran toimituksia, Nro 1457, Suomalaisen Kirjallisuuden Seura, Helsinki, Sivut 721-748.

http://hdl.handle.net/10138/323309

cc_by_nc_nd

publishedVersion

Downloaded from Helda, University of Helsinki institutional repository.

This is an electronic reprint of the original article.

This reprint may differ from the original in pagination and typographic detail.

Please cite the original version. 


\section{Luku 16 Antropologinen lingvistiikka}

\section{Ekaterina Gruzdeva}

(1) https://orcid.org/0000-0001-8898-649X

Juha Janhunen

(1) https://orcid.org/0000-0003-1242-8808

\section{Mikä?}

Antropologia tieteenalan nimityksenä tarkoittaa sananmukaisesti "oppia" (kreikan -logía) "ihmisestä" (kreikan ánthrôpos). Antropologinen lingvistiikka on siis kielitieteen osa-alue, joka on kiinnostunut kielen kulttuurisesta ja sosiaalisesta merkityksestä. Siinä yhdistyvät kielitieteen, kulttuurientutkimuksen ja yhteiskuntatieteiden menetelmät.

\section{Katso myös:}

Luku 5 Lingvistinen etnografia toimintayhteisöissä

Luku 13 Kielen dokumentointi ja kieliopin kuvaus

Luku 14 Kielitypologian menetelmät

Luku 15 Historiallinen ja vertaileva kielentutkimus

Luku 21 Sosiolingvistiikka 


\section{Johdanto: mitä antropologinen lingvistiikka on?}

Antropologia tieteenalan nimityksenä tarkoittaa sananmukaisesti "oppia" (kr. -logía) "ihmisestä" (kr. ánthrôpos). Ihmistä voidaan tutkia fyysisenä lajina (fyysinen antropologia), kulttuuria luovana ja kantavana olentona (kulttuuriantropologia) tai myös yhteisöjä rakentavana ja ylläpitävänä ryhmän jäsenenä (sosiaaliantropologia). Koska ihmisen tärkein ominaisuus sekä kulttuurin että yhteisöllisyyden kannalta on kieli, myös kieltä voidaan tutkia antropologian kannalta ja antropologian menetelmin. Tätä tutkimusta tekee antropologinen lingvistiikka.

Antropologinen lingvistiikka on siis kielitieteen osa-alue, joka on kiinnostunut kielen kulttuurisesta ja sosiaalisesta merkityksestä. Kulttuuriset ja sosiaaliset ilmiöt näkyvät aina sekä kielen substanssissa että rakenteessa - sanastossa ja kieliopissa - mutta myös kielen kontekstissa - kieliyhteisön rakenteessa, historiassa ja kontakteissa muiden kieliyhteisöjen kanssa. Aika ja paikka ovat keskeisiä kielen antropologisen kontekstin ymmärtämiseksi. Hyvin erityyppisen näkökulman kieleen verrattuna antropologiseen lingvistiikkaan muodostavat esimerkiksi erilaiset kielen formaalit teoriat, joiden avulla kieliä voidaan kuvata järjestelminä riippumatta niiden kontekstista.

Koska kulttuurit ja ihmisyhteisöt voivat olla keskenään hyvin erilaisia, antropologisessa lingvistiikassa korostuu kielten erilaisuus eli diversiteetti. Maapallolla puhutaan tällä hetkellä noin 6 ०००-7 ००० kieltä, ja antropologinen lingvistiikka kohdistaa huomionsa erityisesti niihin maailman kieliin, joita ei vielä ole kuvattu tai edes luokiteltu ja jotka lisäksi ovat nopeassa tahdissa katoamassa kolonialismin ja globalisaation aiheuttamassa yleismaailmallisessa murroksessa. Vaikka antropologinen lingvistiikka voi hyödyntää yleisten kieliteorioiden ja kielitypologian luomia malleja, se pyrkii näkemään näiden taakse ja löytämään ne kontekstuaaliset ominaisuudet, jotka tekevät kustakin kielestä ainutkertaisen.

Antropologinen lingvistiikka tutkii myös sitä, kuinka kieltä käytetään suhteessa kielten sisäiseen ja ulkoiseen variaatioon. Hyvin suuri osa ihmiskunnasta käyttää päivittäin useita kieliä tai kielimuotoja - murteita, 
tyylejä ja rekistereitä -, ja tämän moninaisuuden takana on monenlaisia sosiaalisia, esimerkiksi etnisyyteen, sukupuoleen, kulttuuriin ja yhteiskuntarakenteisiin liittyviä tekijöitä. Näitä tekijöitä eivät formaalit kieliteoriat tai kognitiivinen lingvistiikka yleensä huomioi, mutta ne kuuluvat erityisesti antropologisen lingvistiikan kompetenssiin. Tämä merkitsee samalla sitä, että antropologinen lingvistiikka on luonteeltaan monitieteistä ja tieteidenvälistä tutkimusta: siinä yhdistyvät kielitieteen, kulttuurientutkimuksen ja yhteiskuntatieteiden menetelmät.

Antropologinen lingvistiikka ei ole kuitenkaan alana täysin yhtenäinen, vaan sen sisällä on erilaisia painotuksia, ja myös sen ulkoiset rajat muihin tieteisiin ovat liukuvat. Näitä eroja ja rajoja heijastavat ne erilaiset termit, joilla tutkijat operoivat. Seuraavassa tarkastellaan antropologisen lingvistiikan suhdetta joihinkin lähialoihin.

Antropologinen lingvistiikka ja lingvistinen antropologia. Antropologisen lingvistiikan rinnalla puhutaan usein lingvistisestä antropologiasta. Vaikka näitä termejä voidaan käyttää samassa merkityksessä, niiden välillä voidaan nähdä myös painotusero. Antropologille kieli on ennen kaikkea väline, jonka kautta voidaan lähestyä kulttuurin ja yhteiskunnan rakenteita, kun taas lingvistille kieli on varsinainen tutkimuskohde, jossa näkyvät ympäröivän kulttuurin ja yhteiskunnan rakenteet. Joidenkin tutkijoiden mielestä on ylipäänsä turha puhua lingvistisestä antropologiasta, koska kieli ihmisen lajiominaisuutena kuuluu aina antropologian piiriin. Toiset taas pitävät myös antropologista lingvistiikkaa ensisijaisesti antropologiana, koska erityisesti anglosaksista lingvistiikkaa ovat viime vuosikymmeninä dominoineet antropologialle vieraat universalistiset ja formalistiset näkemykset.

Selvästi antropologian piiriin kuuluvat joka tapauksessa ne kysymykset, jotka liittyvät kieleen ihmisen lajiominaisuutena. Nykyään puhuttavat kielet antavat vain hyvin kapean näkökulman ihmiskielen esihistorialliseen taustaan. Kieli on ollut olemassa ehkä jo satoja tuhansia vuosia, ja sen fyysistä alkuperää voi tutkia lähinnä vain fossiililöydöistä tehtyjen johtopäätösten avulla (paleoantropologia). Arviot muinaisesta kielidiversiteetistä edellyttävät myös ennen kaikkea antropologista tietoa ihmisyhteisöjen koosta, sijainnista ja elintavoista. Varsinainen antropologinen lingvistiikka liikkuu yleensä lähempänä nykyaikaa tai 
suorastaan nykyajassa, jolloin kieltä voidaan havainnoida sen välittömässä kulttuurisessa ja sosiaalisessa kontekstissa.

Antropologinen lingvistiikka ja etnolingvistiikka. Antropologisen lingvistiikan synonyyminä käytetään usein myös termiä etnolingvistiikka. Etnolingvistiikka viittaa sananmukaisesti etnisyyteen ja etnisiin ryhmiin (kr. éthnos), ja koska yksi antropologisen lingvistiikan painopistealueista on tyypillisesti pienten etnisten ryhmien aikaisemmin tutkimattomien kielten kartoitus ja dokumentaatio, etnisyyteen viittaaminen on paikallaan. Kyse on kuitenkin myös terminologisten traditioiden erosta: etnisten ryhmien tutkimus tunnetaan varsinkin Euroopassa perinteisesti "etnologiana", kun taas Pohjois-Amerikassa puhutaan useammin "antropologiasta" (tarkoittaen erityisesti kulttuuriantropologiaa).

On kuitenkin hyvä muistaa, että sekä lingvistinen antropologia että antropologinen lingvistiikka voivat tutkia myös muita kuin kielen etnisiä ulottuvuuksia. Esimerkiksi suurkaupunkien sosiaalisen diversiteetin tutkimuksesta puhutaan usein urbaanina antropologiana, ja myös antropologinen lingvistiikka voi tutkia kielten kontekstuaalisia ulottuvuuksia etnisyydestä riippumatta. Tältä kannalta etnolingvistiikka on parhaiten ymmärrettävissä antropologisen lingvistiikan alalajina, jossa huomio kiinnitetään nimenomaan kielen ja etnisyyden yhteyksiin. Tämä on sinänsä tärkeä yhteys, koska kieli on kiistämättä tärkein etnistä identiteettiä ylläpitävä tekijä.

Antropologinen lingvistiikka ja sosiolingvistiikka. Koska antropologinen lingvistiikka tarkastelee kieltä suhteessa kieliyhteisöön ja sen sosiaalisiin rakenteisiin, se on tutkimusalana lähellä myös sosiolingvistiikkaa. Kieliyhteisön koko ja sosiaalinen koostumus, muun muassa puhujien ikä- ja elinkeinorakenne sekä liikkuvuus, vaikuttavat olennaisella tavalla siihen, miten kieli elää ja toimii ympäristössään, ja tämän vaikutuksen tutkimus kuuluu luonnostaan antropologisen lingvistiikan piiriin. Enemmän kuin "puhtaassa" sosiolingvistiikassa antropologisessa lingvistiikassa korostuvat kuitenkin kielen sosiaalisen variaation kulttuuriset ja etniset taustatekijät.

Sosiolingvistiikan kehittämiä metodeja voidaan joka tapauksessa menestyksellisesti hyödyntää antropologisessa lingvistiikassa, eikä jyrkkää rajaa näiden lähestymistapojen välille voida vetää (ks. Sosiolingvistiikka 
tässä kirjassa). Antropologisen lingvistiikan sosiolingvistiset ulottuvuudet sivuavat jossain määrin myös psykolingvistiikkaa, mutta tutkimusalana psykolingvistiikka on kauempana antropologisesta näkökulmasta ja kuuluu enemmän kognitiivisen kielentutkimuksen kenttään. Psykolingvistiikka tutkii ennen kaikkea kielen suhdetta kognitiivisiin prosesseihin (ajatteluun), eivätkä kielen kulttuuriset ja sosiaaliset ulottuvuudet tyypillisesti ole mukana sen kysymyksenasetteluissa.

Antropologinen lingvistiikka ja ekolingvistiikka. Vasta varsin hiljattain antropologisen lingvistiikan rinnalle on kehittynyt ekolingvistiikkana tunnettu tutkimussuuntaus, jota on kehittänyt mm. Australiassa vaikuttava saksalainen lingvisti Peter Mühlhäusler (I996). Ekolingvistiikka eli lingvistinen ekologia ottaa keskeisen näkökulmansa ekologiasta, joka tutkii erityisesti luonnonympäristön rakenteita. Ekolingvistiikka on alana lähellä sosiolingvistiikkaa mutta eroaa siitä muun muassa sikäli, että se ottaa kielen sosiaalisen ympäristön lisäksi huomioon myös fyysiset ympäristötekijät, esimerkiksi ilmaston ja kasvillisuuden, joilla puolestaan on suora vaikutus kieliyhteisön kulttuuriin, elinkeinorakenteeseen ja kokoon.

Ekolingvistiikka tarjoaa antropologiselle lingvistiikalle erityisen käyttökelpoisia malleja kielten historiallisen leviämisen, jakautumisen, vuorovaikutuksen ja viime kädessä uhanalaisuuden tutkimukseen. Kielet muodostavat, kuten elävän luonnon lajit, ekologisia järjestelmiä, joiden pysyvyydelle on olennaista tasapainon säilyminen. Ekolingvistiikka, yhtä vähän kuin antropologinen lingvistiikkakaan, ei kuitenkaan välttämättä ota kantaa tasapainon säilymisen puolesta, vaan se voi yhtä hyvin tutkia niitä tilanteita, joissa tasapaino horjuu.

\section{Antropologisen lingvistiikan taustaa}

Antropologinen lingvistiikka on kehittynyt yhdessä muun kielitieteen kanssa, ja on vaikea sanoa, missä sen varsinaiset juuret ovat. Voidaan jopa ajatella, että lähes kaikki sellainen kielentutkimus, joka hakee 
aineistonsa puhutuista kielistä, on antropologista lingvistiikkaa riippumatta siitä, millä nimellä tällaista tutkimusta kulloinkin on kutsuttu. Puhuttuja kieliä taas on ainakin eurooppalaisessa kontekstissa tutkittu jo vähintään löytöretkien ja reformaation ajoista alkaen.

Amerikkalainen antropologia. Usein antropologisen lingvistiikan katsotaan olevan lähtöisin I80o-luvun lopun pohjoisamerikkalaisesta antropologiasta, joka alkoi tutkia intiaanikansoja ja niiden kieliä - samalla kun intiaaniheimoja systemaattisesti tuhottiin Yhdysvaltain laajentuessa kohti länttä. Tämän tutkimuksen pioneerina ja koko antropologian pohjoisamerikkalaisen koulukunnan perustajana tunnetaan Franz Boas (I858-I942), jonka johdolla valmistui muun muassa massiivinen teossarja Handbook of American Indian Languages (Boas I9II-I922). Boasin koulukuntaan liittyivät myös venäläiset Vladimir Bogoraz (I865-I936) ja Vladimir Jochelson (1855-1937), joiden tutkimuskohteena olivat Koillis-Siperian kansat ja kielet.

Boasin koulukunta korosti alusta alkaen sitä, ettei ole olemassa "primitiivisiä" kieliä tai kansoja, vaan kaikki kielet ja kulttuurit ovat omalla tavallaan yhtä kompleksisia. Samalla ymmärrettiin, että kaikki kielet ja kulttuurit ovat keskenään hyvin erilaisia, ja tämän erilaisuuden kartoittamiseksi ne tuli perusteellisesti dokumentoida. Dokumentaatio tapahtui kenttätyön avulla välittömässä kontaktissa kielen puhujiin, ja kenttätyötä pyrittiin tekemään erityisesti sellaisilla alueilla ja sellaisten kielten parissa, joita vielä ei ollut kuvattu. Näitä alueita olivat Pohjois-Amerikan lisäksi erityisesti Keski- ja Etelä-Amerikka mutta myös Australia, Oseania, Afrikka sekä suuret osat Aasiaa - alueita, jotka kaikki ovat nykyäänkin antropologisen lingvistiikan keskeisiä kohteita.

Boasin koulukunnalle oli - ja on - ominaista myös neopositivistinen käsitys siitä, että empiirisesti "aitoa" kieliainesta on ainoastaan se, joka on kielenpuhujan spontaanisti tuottamaa ja puhujalta suoraan dokumentoitua. Tältä pohjalta tutkimus keskittyi erityisesti tekstimuotoisten kielennäytteiden keräämiseen. Teksteistä voitiin poimia esimerkkejä sekä sanaston että kieliopin tutkimukseen, ja niitä voitiin käyttää myös lähteinä kulttuuria lähestyttäessä. Ylipäänsä kielen ja kulttuurin tutkimusta ei boasilaisessa käsityksessä eroteta toisistaan, koska tutkimuksessa lähdetään siitä, että kulttuuria voi tutkia vain kielen kautta ja että 
kielessä joka tapauksessa heijastuvat puhujien edustaman kulttuurin ominaisuudet.

Eurooppalainen etnologia. On kuitenkin virhe pitää antropologista lingvistiikkaa yksinomaan pohjoisamerikkalaisena "keksintönä", sillä ala on ollut pitkään tunnettu ja harrastettu myös Euroopassa. Boasin eurooppalaisena vastineena pidetään usein Englannissa vaikuttanutta puolalaista Bronisław Malinowskia (I884-I942), jonka kohdealueena olivat Tyynenmeren saaret, mutta hänen rinnallaan on mainittava niin ikään Englannissa uransa luonut suomenruotsalainen Edward Westermarck (1862-I939), joka teki kenttätyönsä Pohjois-Afrikassa. Malinowski ja Westermarck kuuluvat eittämättä modernin etnologian perustajahahmoihin, mutta myös heillä oli merkittävä edeltäjä, Australiassa toiminut venäläinen Nikolai Miklukho-Maklai (I846-I888), joka yhtenä ensimmäisistä kartoitti kentällä Tyynenmeren kansoja.

On tosin jossain määrin kyseenalaista, voidaanko sen paremmin pohjoisamerikkalaisia antropologeja kuin eurooppalaisia etnologejakaan pitää nimenomaan lingvistisen antropologian edelläkävijöinä, sillä heille kaikille kieli oli ensi sijassa vain väline, jonka kautta päästiin tutkimaan kulttuurin syvempiä rakenteita. Sinänsä on selvää, että kulttuuria tai sosiaalisia rakenteita ei voi tutkia ilman niitä kannattavan yhteisön kieltä, mutta kielentutkimus eroaa kulttuurientutkimuksesta juuri siinä, että sille kieli ei ole väline vaan varsinainen tutkimuskohde. Voi sanoa, että kulttuurientutkimus on parhaimmillaankin vain välineellistettyä kielentutkimusta.

Kielitieteilijät lähetystyössä. Eräänlaista välineellistettyä kielentutkimusta edustaa myös se traditio, jonka perimmäisenä tarkoituksena on uskonnon levittäminen ja sen kautta kulttuurisen yhdenmukaisuuden edistäminen. Kristilliset lähetyssaarnaajat ovat jo vuosisatoja, aluksi kolonialismin ja nyttemmin globalisaation hengessä, kartoittaneet maailman kielellistä moninaisuutta voidakseen levittää sanomaansa myös sellaisille kansoille, joiden kielillä ei ole kirjallista perinnettä. Tätä toimintaa ovat harjoittaneet kaikki kristilliset suuntaukset, mutta erityisen vahvaksi sen asema on muodostunut Pohjois-Amerikassa syntyneiden protestanttisten liikkeiden ja vapaakirkollisten suuntausten keskuudessa. Esimerkiksi suomalaisen afrikanistiikan perinne on syntynyt lähes yksinomaan tältä pohjalta. 
Uskonnollispohjaista kielentutkimusta ei ole syytä vähätellä, sillä se on vuosikymmenien ajan, erityisesti juuri Pohjois-Amerikassa, ylläpitänyt antropologisen lingvistiikan traditiota, samalla kun muu kielitiede on painottunut voimakkaammin universalistisen ja kognitiivisen tutkimuksen suuntaan. Valtaosa aikaisemmin tutkimattomien kielten kuvauksista syntyy nykyäänkin kristillisten yhteisöjen tuella ja rahoituksella. Keskeinen rooli tässä toiminnassa on "Kielitieteen kesäkoululla" (Summer Institute of Linguistics eli SIL International), joka systemaattisesti kouluttaa kielitieteellisesti päteviä lähetystyöntekijöitä eri puolille maailmaa. Tunnetuin tämän koulun kasvateista oli Kenneth L. Pike (I9I2-2000), jota voi perustellusti pitää yhtenä antropologisen lingvistiikan suurista nimistä.

Suomalainen etnolingvistiikka. On monia syitä korostaa Suomen merkitystä antropologisen lingvistiikan historiassa. Suomalaisilla tutkijoilla oli Venäjän yhteydessä poikkeuksellisen hyvät mahdollisuudet tutkia Venäjän ja Siperian kielellistä moninaisuutta, ja tähän oli myös hyvät syyt, sillä haluttiin löytää suomalaisten kielisukulaiset ja määrittää "Suomen suvun" rajat. Tästä tutkimusperinteestä, jonka keskeisenä metodina oli kielitieteellinen kenttätyö, nousivat Suomen "kansalliset kielitieteet" uralistiikka (fennougristiikka) sekä myös altaistiikka, jotka myöhemmin levisivät maailmalle ja tulivat osaksi kansainvälistä kielentutkimusta.

Suomalaisen etnolingvistiikan perustajina voi pitää Anders Johan Sjögreniä (I794-I855) ja Matthias Alexander Castrénia (I8I3-I852), joiden tutkimat kielet yhdessä kattoivat suurimman osan Venäjän imperiumia Kaukasiaa ja Siperiaa myöten. Tätä perinnettä jatkoi I883 perustetun Suomalais-Ugrilaisen Seuran tuella suuri joukko suomalaisia kielentutkijoita, jotka etnolingvistiikan hengessä dokumentoivat kentällä sekä kieliä että niiden konteksteja. Tyypillistä tälle vaiheelle oli, että kukin tutkija yleensä erikoistui vain yhteen kieleen tai kielihaaraan, kuten Artturi Kannisto (I874-I943) mansiin, K. F. Karjalainen (I87I-I9I9) hantiin ja Toivo Lehtisalo (I887-I962) nenetsiin. Monipuolisempaa lähestymistapaa edustivat Kai Donner (I888-I935) ja G. J. Ramstedt (1873-I950), joista viimeksi mainittu tunnetaan nimenomaan modernin altailaisen kielentutkimuksen perustajana.

Suomalainen etnolingvistiikka syntyi noin puoli vuosisataa ennen amerikkalaista antropologiaa, mutta koska sen tulokset julkaistiin 
aikoinaan pääasiassa ruotsiksi ja saksaksi, se on tieteenhistoriassa jäänyt angloamerikkalaisen tutkimuksen varjoon. Mielenkiintoista on, että myös suomalaiset tutkijat siirtyivät - Boasin koulukunnasta riippumatta - kohti neopositivistista empirismiä ja keskittyivät yhä enemmän tekstien keruuseen ja yhä vähemmän kielen rakenteen kuvaukseen. Alan uranuurtajat Sjögren ja Castrén käyttivät vielä runsaasti myös elisitaatiomenetelmiä, minkä ansiosta he saattoivat kuvata kielioppia järjestelmällisemmin ja täydellisemmin kuin pelkän tekstiaineiston varassa toimivat seuraajansa.

Saksalainen humanismi. Suomalaisen etnolingvistiikan juuret puolestaan olivat saksalaisen humanismin pohjalta syntyneissä kielitieteen suuntauksissa, jotka johtivat historiallis-vertailevan kielentutkimuksen ja kielitypologian syntyyn (ks. Historiallinen ja vertaileva kielentutkimus; Kielitypologian menetelmät tk.). Tosin historiallis-vertaileva kielentutkimuskin mainitaan usein harhaanjohtavasti anglosaksien keksintönä William Jonesin (I746-I794) intialaisten ja eurooppalaisten kielten sukulaisuutta koskevan lyhyen kannanoton johdosta, mutta alan varsinainen perustaja oli saksalainen sanskritisti Franz Bopp (I79I-I867), joka I8I6 julkaisi systemaattisen esityksen sanskritin, persian, kreikan, latinan ja germaanisten kielten yhteisistä piirteistä (Bopp I8I6). Tämä indoeurooppalaisen kielentutkimuksen perusteos toimi lähtökohtana muiden kielikuntien, myös uralilaisten kielten, vertailevalle tutkimukselle.

Saksalaiseen humanismiin pohjautui viime kädessä myös tanskalaisen Rasmus Raskin (I787-I832) työ. Rask kirjoitti suuren joukon kielioppeja sekä tunnetuista että vähemmän tunnetuista eurooppalaisista kielistä, muun muassa useista germaanisista ja romaanisista kielistä sekä pohjoissaamesta. Hän teki myös matkan Intiaan ja julkaisi kenttätyöhön perustuvia havaintoja joukosta intialaisia kieliä. Raskilla oli merkittävä rooli suomalaisen etnolingvistiikan historiassa, sillä hänen vierailunsa Suomessa I8I8 innoitti Sjögreniä antautumaan kielitieteilijän uralle. Myöhemmin hänen elämäntyönsä innoitti myös Castrénia. Kenttälingvisteinä sekä Sjögren että erityisesti Castrén olivat kuitenkin Raskia huomattavasti merkittävämpiä.

Jo ennen vertailevan kielentutkimuksen metodien muotoutumista saksalaisen humanismin piiristä nousi kielitieteen kannaltakin 
merkittäviä polyhistoreita ja filosofeja, kuten Johann Gottfried von Herder (I744-I803) ja Wilhelm von Humboldt (I767-I835). Teoksessaan kielen alkuperästä Herder (I772) painotti erityisesti kielen merkitystä ajattelun ja sen kautta kulttuurin perustana. Tästä oli vain lyhyt matka Humboldtin näkemykseen kielestä kansallisen identiteetin keskeisenä tunnusmerkkinä, mikä puolestaan oli lähtökohtana suomalaiselle etnolingvistiikalle, joka kielen kautta etsi suomalaisuuden juuria. Humboldt korosti myös kielidiversiteetin tutkimuksen tärkeyttä. Hänen postuumisti I836 julkaistu johdatuksensa Jaavalla puhuttuun kawin kieleen on yksi antropologisen lingvistiikan klassikoista.

Valistusajan kenttätyöperinne. Kielitieteellisen kenttätyön perinne ja kielidiversiteetin tutkimus saivat kuitenkin alkunsa jo valistusajalla, jolloin alettiin systemaattisesti kerätä aineistoa vähän tunnetuista kielistä eri puolilta maailmaa. Tälläkin alalla tutkimusta johtivat saksalaiset polyhistorit, joista monet olivat Venäjän tiedeakatemian palveluksessa ja keräsivät aineistoa Venäjän keisarikunnan kielistä eli lähes koko Keskija Pohjois-Euraasiasta. Kielet olivat tyypillisesti vain yksi dokumentaatiokohde monien muiden joukossa, sillä samalla kuvattiin myös kulttuureja ja historiaa sekä luonnonympäristöä - muun muassa kasveja, eläimiä ja mineraaleja. Etnobotaniikka, joka tutkii kasveja suhteessa niitä käyttävien väestöjen kulttuureihin ja kieliin, on esimerkki tutkimusaloista, jotka versoivat valistusajan kenttätyöperinteestä.

Varsinaisina kielitieteellisinä tuloksina valistusaika dokumentoi lähinnä sanastoa, harvoin kokonaisia fraaseja eikä juuri koskaan kielioppia. Varhaisen pioneerityön tekivät Venäjän Kiinan-lähettiläänä toiminut tanskalainen Eberhard Isbrand Ides (I657-I708), Venäjällä neuvonantajana toiminut hollantilainen Nicholaus Witsen (I64I-I7I7) sekä Venäjälle sotavankina joutunut ruotsalainen Philip Johan von Strahlenberg (I676-I747), joiden kaikkien kuvaukset Pohjois- ja KeskiAasiasta sisältävät myös kieliaineistoa. Ensimmäisen systemaattisen "koko maailman" kielten sanastokokoelman julkaisi Peter Simon Pallas (I74I-I8II), ja vastaavanlaisia sanastoja ilmestyi myöhemmin muitakin, muun muassa Julius Klaprothilta (I783-I835). Näissä sanastoissa kieliä ryhmiteltiin sekä geneettisesti että alueellisesti, ja tältä pohjalta alkoi vähitellen kirkastua kuva maailman kielikunnista ja myös kielialueista. 


\section{Antropologisen lingvistiikan menetelmiä}

Koska antropologisen lingvistiikan kohteena ovat sekä kielet että niiden kulttuuriset, sosiaaliset, alueelliset ja historialliset kontekstit, ala on perusluonteeltaan monitieteinen. Lähtökohtana on kuitenkin aina kulloinkin tutkittava kieli tai kielimuoto, jonka kielitieteellinen kuvaus on edellytyksenä sen kontekstin tutkimiselle. Kun sekä kieli että sen kontekstuaaliset ulottuvuudet on monipuolisesti kartoitettu, voidaan edetä analyysin tasolle ja tehdä esimerkiksi johtopäätöksiä kielen ja kieliyhteisön historiasta sekä vertailuja eri kielten ja kieliyhteisöjen välillä.

Kielitieteellinen kenttätyö. Lähes kaikki antropologinen lingvistiikka perustuu kenttätyön kautta hankittuun aineistoon ja sen analyysiin. Kenttätyön perusmenetelmät ovat samat riippumatta siitä, tutkitaanko kieltä vai sen kontekstia: tutkittava kohde dokumentoidaan mahdollisimman perusteellisesti havainnoinnin ja haastattelujen kautta (ks. Kielten dokumentointi ja kieliopin kuvaus tk.). Kohderyhmänä on yleensä kieliyhteisö, jonka parissa lingvisti viettää riittävästi aikaa voidakseen suorittaa dokumentoinnin monipuolisesti ottaen huomioon yhteisön sisällä vallitsevat sosiaaliset erot esimerkiksi sukupuolten ja ikäryhmien välillä. Kielen jonkinasteiseen dokumentointiin riittää kuitenkin hätätilassa yksikin puhuja, ja varsin monia kieliä onkin dokumentoitu vain yhden - usein viimeisen - puhujan avulla. Pelkän kielen dokumentointi on mahdollista myös laboratorioympäristössä, mutta kieliyhteisön kokonaisprofiilin voi kartoittaa vain kentällä yhteistyössä kielenpuhujien kanssa.

Koska vähänkään isomman kieliyhteisön kaikkia puhujia ei voida tavoittaa, lingvisti käyttää tyypillisesti apunaan pientä joukkoa kielenoppaita (informantteja eli konsultantteja). Kielenoppaiden valinta on ensimmäinen tehtävä kenttätyötä aloitettaessa, ja se on syytä tehdä huolellisesti ottaen huomioon myös sen, että eri kielenoppaat saattavat soveltua erilaisiin tehtäviin. Esimerkiksi kieliopin tai sanaston keruu ei välttämättä onnistu samoilta kielenoppailta, jotka ovat hyviä kertojia ja folkloren taitajia. Eri ikä- ja sukupuoliryhmillä on usein erilainen kompetenssi kielessään, ja heillä saattaa olla myös erilainen 
kaksikielisyysprofiili. Äärimmäisinä tapauksina ovat ryhmät, joissa eri sukupuolet puhuvat eri kieliä.

Osallistuva havainnointi ja elisitointi. Ihannetapauksessa lingvisti saavuttaa käytännön taidon tutkimassaan kielessä eli pystyy käyttämään sitä suoraan kenttätyön apukielenä. Tässä piilee kuitenkin se vaara, että tutkija antaa oman kompetenssinsa vaikuttaa aineistoon. Tästä syystä apuna käytetään usein tutkijan ja kielenpuhujien yhteistä metakieltä - esimerkiksi Venäjän alueella venäjää, Kiinassa kiinaa ja Latinalaisessa Amerikassa espanjaa tai portugalia. Metakielen käyttämisessäkin on kuitenkin ongelmansa, sillä sitä voidaan käyttää ainoastaan kaksikielisten puhujien kanssa ja sen tuoma interferenssi saattaa myös vaikuttaa kerättyyn kieliaineistoon. Joissakin tapauksissa kielentutkijan on paras pitäytyä mahdollisimman huomaamattomassa havainnoinnissa, jonka apuna voidaan käyttää myös teknisiä laitteita. Yksi mahdollisuus on antaa kielenoppaiden itsensä dokumentoida puhettaan ilman tutkijan välitöntä läsnäoloa.

Viime kädessä kaikessa kielitieteellisessä kenttätyössä on tehtävä valinta passiivisen havainnoinnin ja aktiivisen kyselyn välillä. Niin sanotulla osallistuvalla havainnoinnilla (engl. participant observation) lingvisti - kuten antropologikin - kerää empiiristä aineistoa mahdollisimman monenlaisista konteksteista elämällä tutkimansa yhteisön sisällä neutraalina tarkkailijana. Tutkija pyrkii keräämään tutkimastaan kielestä mahdollisimman laajoja ja edustavia tekstejä. Muun muassa sanaston ja kieliopin kokonaisvaltainen dokumentaatio olisi kuitenkin mahdotonta ilman elisitaatiota eli kielenoppaille suunnattua tarkennettua kyselyä, jonka avulla voidaan täydentää muuten puutteellisiksi jääviä tietoja kielen substanssista ja rakenteesta. Vaikka neopositivistinen kielentutkimus piti elisitaation kautta saatuja tietoja "epäaitoina", tiedot kielestä jäisivät poikkeuksetta puutteellisiksi ilman tätä menetelmää. Nykyään elisitaatiota voidaan menestyksellisesti käyttää myös internetin välityksellä.

Kieliaineiston lisäksi antropologinen lingvisti kerää mahdollisimman monipuolista tietoa myös kielen kontekstista. Tätäkään tietoa ei välttämättä saa pelkällä havainnoinnilla, vaan apuna täytyy käyttää haastatteluja. Haastattelut voivat koskea esimerkiksi kielen käyttötilanteita tai 
yksilön henkilöhistoriaa, jolloin voidaan rakentaa niin sanottuja kielellisiä elämäkertoja (engl. linguistic biographies) eli historiallisia kuvauksia siitä, miten ja missä yhteyksissä yksilö ja hänen lähipiiriinsä kuuluvat muut yksilöt ovat elämänsä aikana käyttäneet omaa kieltään ja muita kieliä ja miten tämä tilanne on muuttunut sukupolvesta toiseen.

Tilastollinen tiedonkeruu. Yksi antropologisen lingvistiikan keskeisistä tutkimuskohteista on kielen suhde kieliyhteisöön eli kieltä puhuvaan väestöön. Kokonaiskuvan hankkiminen väestötason kielenkäytöstä edellyttää usein laajamittaista kyselyä, joka voidaan toteuttaa vain systemaattisten ryhmähaastattelujen ja kyselykaavakkeiden avulla. Verrattuna yksilöiden yksityiskohtaisiin syvähaastatteluihin laajamittaiset kyselyt voivat antaa vain huomattavasti yleiskatsauksellisemman käsityksen kielestä ja sen käytöstä, mutta sen etuna on menetelmän suurempi kattavuus ja tiedon yleistettävyys.

Laajamittaisen kyselyaineiston käsittely vaatii demografisten ja tilastollisten analyysimenetelmien käyttöä. Erityisesti demografia eli väestöjen (kr. dêmos) tutkiminen on antropologisen lingvistiikan olennainen aputiede. Maailmassa tällä hetkellä puhuttujen kieliyhteisöjen demografinen profiili on hyvin vaihteleva: on kieliä, joiden puhujia on satoja miljoonia, ja toisia, joita puhuu vain muutama yksilö. Valtaosalla maailman kielistä on muutamasta sadasta muutamaan tuhanteen puhujaa. Tämä suuri vaihtelu, joka ilmenee myös puhujien kaksi- ja monikielisyyden eroissa, tarjoaa haasteita tilastoaineiston keruulle ja käsittelylle. Mitä suurempi kieliyhteisö on, sitä vaikeampi siitä on luoda edes tilastollista kokonaiskuvaa.

Aineiston tallentaminen. Klassinen ja edelleen käyttökelpoinen menetelmä tallentaa kenttätyössä tehtyjä havaintoja on kirjoittaa ne muistiin, mieluiten järjestelmällisellä tavalla ja tiiviissä yhteistyössä kielenoppaan kanssa. Aineiston segmenttirakenteen osoittamiseen käytetään yleensä vakiintuneita foneettisia tarkekirjoitusjärjestelmiä, kohdekielestä riippuen esimerkiksi kansainvälistä foneettista aakkostoa (International Phonetic Alphabet eli IPA) tai suomalais-ugrilaista tarkekirjoitusta (Finno-Ugrian Transcription eli FUT). Monista sittemmin kadonneista kielimuodoista on jäljellä ainoastaan lingvistien tekemiä kenttämuistiinpanoja, ja suuri määrä tällaisia muistiinpanoja odottaa 
edelleen arkistoissa käsittelijäänsä. Kaikki, varsinkaan varhaisemmat kenttätutkijat, eivät kuitenkaan ole käyttäneet yksiselitteistä foneettista notaatiota, minkä takia aineistot ovat jälkikäteen usein vaikeasti tulkittavissa.

Koska kirjallisten muistiinpanojen luotettavuus riippuu aina niiden tekijän tarkkuudesta ja koska varsinkin tekstien muistiinpaneminen vaatii suurta nopeutta, alettiin jo ı80o-luvun lopulla käyttää teknisiä äänentallennuslaitteita ja kokeellis-foneettisia apuvälineitä (ks. Kokeellinen fonetiikka tk.). Vaikka nämä tarjoavat sen ilmeisen edun, että aineisto on myös muiden tutkijoiden ulottuvilla mahdollisimman alkuperäisessä muodossa, tallennusten litteroiminen jälkikäteen on hyvin työlästä ja vaatii tutkijalta joko erittäin hyvää kohdekielen taitoa tai uutta yhteistyötä kielenoppaan kanssa. Ongelmana on ollut myös se, että tallennusformaatit muuttuvat nopeasti eikä vielä hiljattain käytetyillä laitteilla tehtyjä tallennuksia voida välttämättä enää avata. Digitoiminen ei näytä tuovan tähän ongelmaan pysyvää ratkaisua, koska myös digitoinnin formaatit vaihtuvat nopeassa tahdissa ja digitoitu aineistokin on altis fyysiselle kulumiselle.

Joka tapauksessa yleinen suositus on nykyään, että kenttälingvistit käyttävät kenttätyössään audiovisuaalisia apuvälineitä. Näin saatu aineisto voidaan edelleen tallentaa avoimiin lingvistisiin tietojärjestelmiin, kuten eurooppalaiseen korpusprojektiin (European Distributed Corpora Project eli EUDICO), jolla puolestaan on oma äänne- ja muotorakenteen merkintää varten kehitetty visualisointijärjestelmänsä (EUDICO Linguistic Annotator eli ELAN). Suomessa kieliaineistoa voi tallentaa FIN-CLARIN-kielipankkiin, joka kuuluu laajempaan kansainväliseen kielitieteiden CLARIN ERIC -tutkimusinfrastruktuuriin (dokumentaatio- ja tallennusmenetelmistä lisää ks. Kielten dokumentointi ja kieliopin kuvaus tk.).

Lingvistiset menetelmät. Varsinaisen kieliaineiston käsittelyyn antropologinen lingvistiikka käyttää tavanomaisia kielitieteellisen analyysin menetelmiä. Erotukseksi monien teoreettisten koulukuntien lähestymistavoista antropologinen lingvistiikka pyrkii kuitenkin minimoimaan teoreettisten ennakko-oletusten haitalliset vaikutukset. Kokemus osoittaa, että monet kieliteoriat ovat ohimeneviä muotivirtauksia, joille on 
tyypillistä vaikea terminologia, liiallinen formalismi ja dogmatismi. Kun muotivirtaus on ohi, tällaiselta perustalta tehtyä kielen kuvausta on vaikea suhteuttaa yleiseen tietopääomaan. Tästä syystä antropologinen lingvistiikka - kuten myös kielitypologia - kuvaa kieliä mahdollisimman yksinkertaisilla malleilla, jotka lisäksi ottavat huomioon kielten erilaisuuden.

Antropologisen lingvistiikan kuvausmalliksi sopiikin parhaiten niin sanottu peruskielioppiteoria (engl. Basic Linguistic Theory), jossa operoidaan vanhoilla tutuilla kielioppitermeillä (esimerkiksi muotoryhmien ja lauseenjäsenten nimet), yleisesti tunnetuilla perusteorioilla (esimerkiksi fonologinen teoria) ja tavanomaisilla analyyttisillä metodeilla (esimerkiksi morfologinen ja syntaktinen analyysi). Tätä teorianeutraalia kieliteoriaa on puolustanut erityisesti australialainen lingvisti R. M. W. Dixon (2009). Lähtökohtana on, että kieliaineiston hallinnan tulisi käydä teorioiden edellä. Tarkoituksena on saattaa aineisto sellaiseen muotoon, että se on sekä eri lingvististen teorioiden kannattajien että tarvittaessa myös ei-lingvistien helposti ymmärrettävissä. Näin analysoitua aineistoa voi tietysti myöhemmin käyttää myös monimutkaisemman teorianmuodostuksen pohjana.

Filologiset menetelmät. Vaikka antropologisessa lingvistiikassa aineisto tyypillisesti kerätään kenttätyön avulla suoraan elävien kielten puhujilta, siinä voidaan hyödyntää myös kirjoitettuun muotoon tallennettuja kieliaineistoja, jolloin käytetään filologian menetelmiä. Erotukseksi lingvistiikasta filologia käsitetään usein tieteenalaksi, joka keskittyy kirjoitettujen lähteiden eli tekstien ja tekstikorpusten sisältöön esimerkiksi historialliselta tai kirjalliselta kannalta (ks. Näkökulmia filologiseen tutkimukseen tk.). Kirjallista aineistoa voidaan kuitenkin tutkia myös lingvistisesti, ja silloin liikutaan antropologisen lingvistiikan alueella. Mitä vanhemmasta aineistosta on kysymys, sitä suurempi merkitys lingvistiikalla on aineiston ymmärtämiselle.

On monia muinaisia kieliä, jotka tunnetaan ainoastaan kirjallisista lähteistä. Vain harvoja näistä kielistä - esimerkiksi etruskia - on kirjoitettu nykypäivään asti käytetyillä kirjoitusjärjestelmillä. Tyypillisempää on, että sekä kieli että sen kirjoitusjärjestelmä ovat jääneet pois käytöstä. Tällöin lingvistin ensimmäinen tehtävä on desifroida eli tulkita 
tuntematon kirjoitusjärjestelmä. Tällä saralla onkin saavutettu hämmästyttäviä tuloksia: monet tärkeät muinaiset kielet - esimerkiksi muinaisegypti, sumeri, akkadi, heetti, arkaainen kreikka, muinaisturkki ja kitaani - tunnetaan vain sen ansiosta, että niiden kirjoittamiseen käytetyt kirjoitusjärjestelmät on onnistuttu avaamaan. Näin saadulla aineistolla on poikkeuksellisen suuri arvo myös lingvistisesti, sillä se antaa kuvan muinaisesta kielidiversiteetistä ja sen kehityksestä aikojen kuluessa.

Diakroniset menetelmät. Antropologisen lingvistin keräämä synkroninen kenttäaineisto toimii yleisenä tietopohjana tutkittavan kielen tuntemukselle, ja tätä aineistoa voidaan käyttää monenlaisiin sekä tieteellisiin että käytännöllisiin tarkoituksiin. Yksi merkittävä tieteellinen käyttöalue on diakroninen eli historiallinen kielentutkimus, jonka avulla lähestytään tutkittavan kielen aikaisempia vaiheita ja kehitystä. Sikäli kuin tukena ei ole käytettävissä filologista aineistoa, tutkimus käyttää niitä historiallis-vertailevan kielentutkimuksen menetelmiä (ks. Historiallinen ja vertaileva kielentutkimus tk.), jotka kehitettiin Saksassa ı8oo-luvun alkupuolella ja joita siellä aluksi sovellettiin indoeurooppalaisten kielten tutkimukseen. Tutkimusalue on edelleen ajankohtainen, sillä maailmassa on useita satoja kielikuntia ja suurta osaa niistä ei vielä ole edes alustavasti analysoitu.

Voi sanoa, että historiallinen ja vertaileva kielentutkimus on vain yksi laajasti käsitetyn antropologisen lingvistiikan osa-alueista. Siinä missä kenttätyö antaa kielestä synkronisen kuvan, historiallinen ja vertaileva tutkimus avaa ikkunan diakroniaan. Jos kielellä on sukukieliä, näiden keskinäisellä vertailulla voidaan rakentaa käsitys kielen ja sen sukukielten aikaisemmista vaiheista ja rekonstruoida eritasoisia kantakieliä. Jos kielellä ei ole säilyneitä sukulaisia eli jos se on genealoginen isolaatti, sen sisältämä synkroninen informaatio - esimerkiksi morfofonologia - voi silti antaa mahdollisuuden diakroniseen analyysiin sisäisen rekonstruktion menetelmällä. Myös vertailu erisukuisiin naapurikieliin, joiden kanssa kieli on ollut historiallisessa kontaktissa, antaa diakronista tietoa kielen kehityksestä ja kronologiasta. 


\section{Antropologisen lingvistiikan teoriapohja}

Antropologinen lingvistiikka on perusluonteeltaan empiirinen tieteenala, jonka ei päämääräänsä toteuttaakseen tarvitse välttämättä mennä aineiston dokumentaatiota, järjestelyä ja tallentamista pitemmälle. Kielitieteen sisällä kulkee vanha juopa, jonka toisella puolella ovat ne kielitieteilijät, jotka tutkivat "kieltä" (engl. language), ja toisella ne, jotka tutkivat "kieliä" (languages). Antropologinen lingvistiikka tutkii luonnollisesti kieliä ja niiden kautta kielten moninaisuutta ja kohdistaa huomionsa erityisesti niihin piirteisiin, jotka erottavat kieliä toisistaan, eikä niihin, jotka universaalisti yhdistävät kaikkia kieliä.

Mitä enemmän maailman kieliä on tutkittu, sitä ilmeisemmäksi on käynyt, että kielten välillä on hämmästyttävän suuria eroja. Vastaavasti niin sanottujen kielellisten universaalien eli kaikille kielille yhteisten ominaisuuksien määrä on osoittautunut hyvin pieneksi, minkä lisäksi yhteiset piirteet ovat tyypillisesti hyvin triviaaleja ja koskevat lähinnä vain kaikkein perustavimpia kielellisiä kategorioita (esimerkiksi vokaalit vs. konsonantit, äännesegmentit vs. sanat vs. fraasit). Toisaalta myös hyvinkin keskeiset kielen osa-alueet (esimerkiksi tavurakenne, sanajärjestys, sanaluokat, muoto-oppi, lauserakenne) voivat maailman kielissä olla hyvin erilaisia (näitä eroja tutkii kielitypologia, ks. Kielitypologian menetelmät tk.). Tämä erilaisuus merkitsee myös sitä, että ne kieliteoriat, jotka perustuvat vain yhden kielen - esimerkiksi englannin kielen - faktoihin, eivät voi olla yleispäteviä.

Koska kuitenkin antropologisen lingvistiikan kohteena ei ole ainoastaan kieli vaan myös sen konteksti, tämän tieteenalan omat teoreettiset kysymyksenasettelut koskevat nimenomaan kielen ja sen kontekstin välistä suhdetta. Konteksti puolestaan sisältää sekä luonnonympäristön että kulttuurin ja sosiaaliset suhteet. Viime kädessä kontekstiin kuuluu myös ajattelu.

Kielellinen relativismi. Kaikkein keskeisin teoreettinen kysymyksenasettelu antropologisen lingvistiikan historiassa koskeekin kielen ja ajattelun suhdetta. Toisin kuin joissain kielentutkimuksen suuntauksissa, joissa lähdetään siitä, että ihmislajin ajattelu toimii universaalisti 
samoista lähtökohdista, antropologinen lingvistiikka pitää mahdollisena sitä, että kieli vaikuttaa ajatteluun, toisin sanoen, että ihmiset ajattelevat eri tavoin riippuen siitä, mitä kieltä he puhuvat. Tämä niin sanotun kielellisen relativismin näkökulma tunnetaan myös nimellä Sapir-Whorf-hypoteesi (engl. Sapir-Whorf hypothesis) sitä ensimmäisinä kehittäneiden amerikkalaisten lingvistien Edward Sapirin (I884-1939) ja Benjamin Whorfin (I898-I94I) mukaan (Sapir I949; Whorf I956).

Kielellinen relativismi näkyy käytännössä monissa kielenkäytön yksityiskohdissa. Esimerkiksi viittausjärjestelmät, joilla kielen puhujat viittaavat aikaan ja paikkaan käyttäen deiktisiä sanoja (erityisesti pronomineja) tai muotoja, vaihtelevat suuresti kielestä toiseen. Puhujan, joka hallitsee vain oman kielensä viittausjärjestelmän, on usein vaikea hahmottaa toisen kielen viittausjärjestelmän sisäistä logiikkaa. Klassisen esimerkin saman fyysisen todellisuuden erilaisista kielisidonnaisista hahmotusmalleista tarjoavat myös väritermit, joiden määrä ja suhde värikarttaan vaihtelee. On lisäksi todettu, että värijärjestelmä täydentyy eri kielissä uusilla väritermeillä tietyn, lähes universaalin kaavan mukaan. Tyypillinen on esimerkiksi Itä-Aasian kielissä vallitseva viiden väritermin järjestelmä (valkoinen - musta - punainen - keltainen - sininen/vihreä), kuten Brent Berlin ja Paul Kay (I969) ovat klassisessa tutkimuksessaan osoittaneet.

Johtopäätöksiä kielen vaikutuksesta ajatteluun ei kuitenkaan pidä viedä liian pitkälle. Joskus on esitetty, että jopa kielen perustypologia, esimerkiksi sanajärjestys, voi vaikuttaa yksilön ja yhteisön käyttäytymiseen tai vaikkapa onnettomuusalttiuteen eri tilanteissa. Näin ei varmaankaan ole. Yhtä epätodennäköistä on, että jos kielessä ei ole tempusjärjestelmää, sen puhujilta puuttuisi käsitys ajasta. Kysymys on enemmänkin siitä, että eri kielet ilmaisevat eri asioita eri tavoin, ja asiat, jotka yhdessä kielessä ilmaistaan kieliopin keinoin, voidaan toisessa kielessä ilmaista sanaston avulla tai jättää kokonaan ilmaisematta. Se, mitä kategorioita kieli ilmaisee, ei välttämättä korreloi sen kanssa, kuinka kielen puhujat hahmottavat todellisuuden.

Ympäristön heijastuminen kieleen. Vaikka on siis epätodennäköistä, että kieli suoranaisesti vaikuttaisi ajatteluun, on selvää, että ympäristö vaikuttaa kieleen, ja tämän vaikutuksen analysointi 
kuuluu antropologisen lingvistiikan keskeisiin teoreettisiin teemoihin. Jo Ferdinand de Saussure (I857-I9I3), jota tosin ei varsinaisesti voi pitää antropologisen lingvistiikan edustajana, esitti, että "kansakunnan tavat heijastuvat sen kieleen ja kieli muokkaa kansakuntaa" (de Saussure 20I4). Yksiselitteisin yhteys vallitsee ympäristön ja sanaston välillä: jokaisessa kielessä on runsaasti erikoistunutta sanastoa, joka vastaa sen puhujien luonnonympäristöä ja kulttuuri-identiteettiä. Tunnettua on, että esimerkiksi eskimokielissä on monipuolinen lumisanasto. Metsästykseen tai kalastukseen erikoistuneilla kieliyhteisöillä on vastaavasti näihin elinkeinoihin liittyvää erikoissanastoa, jota on mahdotonta kääntää suoraan muunlaista elintapaa edustavien väestöjen puhumille kielille.

Sanaston sisällä erottuu myös suljettuja järjestelmiä, jotka ovat erityisen kulttuurisidonnaisia. Paljon tutkittu antropologien ja siis myös lingvistien kohde on sukulaisuussanasto (engl. kinship terminology), joka heijastaa kieliyhteisön sosiaalisia suhteita (Morgan I87I). Sosiaaliset erot ja hierarkiat voivat näkyä myös siinä, miten sanoja käytetään ja miten eri yhteisön jäseniä ja ryhmiä puhutellaan missäkin tilanteessa: esimerkiksi antamista ja saamista tarkoittavat sanat voivat vaihdella sen mukaan, mitkä antajan ja saajan sosiaaliset suhteet ovat. Monissa yhteisöissä on myös eroja naisten ja miesten kielten välillä. Sosiaalisia suhteita osoitetaan kielellisin keinon muun muassa monissa Itä-Aasian kielissä (esimerkiksi japanissa ja koreassa). Eroja naisten ja miesten kielessä on niin ikään joissakin Itä- ja Pohjois-Aasian kielissä (esimerkiksi japanissa ja tshuktshissa).

Lingvistisesti erityisen mielenkiintoisia ympäristön kielivaikutukset ovat silloin, kun niillä on yhteys kielen rakenteeseen. Sosiaaliset suhteet voivat ilmetä sanaston lisäksi myös kieliopissa erilaisina kohteliaisuustasoina, joilla voi olla esimerkiksi morfologinen ilmiasu (Brown \& Levinson I987). Tavallista on myös, että kielissä on genus- ja luokkajärjestelmiä, joiden avulla sanasto luokitellaan fyysisen sukupuolen tai muun ulkoisen ominaisuuden mukaan luokkiin. Luokilla voi olla morfologiset indikaattorit, ja ne voivat kongruenssin kautta ilmetä myös syntaksissa. Lisäksi eri luokkiin viittaaminen saattaa tapahtua erityisen klassifikaattorijärjestelmän avulla, ja myös deiktiset sanat, kuten pronominit, korreloivat yleensä luokkien kanssa (Aikhenvald \& Mihas 20I9). 
Paljon kiistelty kysymys on, voiko myös luonnonympäristö vaikuttaa kielen rakenteeseen. On esitetty, että esimerkiksi kylmässä ilmanalassa puhuttujen kielten äännejärjestelmät välttävät huuliäänteitä (labiaaleja), kuten näyttää olevan tilanne eskimo- ja aleuttikielissä. On myös ehdotettu, että agglutinatiivinen kielityyppi olisi erityisen tavallinen nomadikansojen kielissä, jolloin se korreloisi näiden kansojen tyypillisesti aukeiden luonnonympäristöjen sekä kieliyhteisöjen laajojen nautintaalueiden kanssa. Toistaiseksi evidenssi tällaisten korrelaatioiden puolesta näyttää olevan heikkoa.

Kieli ja etnos ajassa ja paikassa. Kieli on laajalti hyväksytyn näkemyksen mukaan tärkein etnisyyden tunnusmerkki. Diakronisen kielentutkimuksen menetelmät antavat mahdollisuuden seurata kieltä parhaassa tapauksessa useita tuhansia vuosia ajassa taaksepäin. Etnisyyttä määrittävät kuitenkin myös kieliyhteisön kulttuuriset piirteet ja biologinen perimä. On hyvä ymmärtää, että kieli, kulttuuri ja biologiset ominaisuudet eivät välttämättä periydy samassa linjassa vaan enimmäkseen toisistaan riippumatta. Tästä syystä kieliyhteisön etnistä identiteettiä ei voida seurata taaksepäin yhtenäisenä kokonaisuutena, vaan kielellä, kulttuurilla ja biologisilla ominaisuuksilla on kullakin oma taustansa. Lisäksi vain kielen taustaa voidaan seurata yhtenäisenä linjana, jonka määrittää sen polveutuminen aikaisemmista kielimuodoista ja kantakielistä.

Välittömästi historiallis-vertailevan kielentutkimuksen synnyttyä heräsi myös pyrkimys yhdistää kielten ja kielikuntien varhaisvaiheita konkreettisiin aikoihin ja paikkoihin sekä myös muinaisiin väestöihin. Tämä kysymyksenasettelu on edelleen relevantti, ja sitä voidaan pitää antropologisen lingvistiikan tärkeimpänä diakronisena teemana. Paitsi yksittäisten kielten ja kielikuntien historiaa tutkimus pyrkii selvittämään myös kokonaisten maantieteellisten alueiden kielellistä taustaa. Vaikka kaikilla kielillä on puhuma-alueensa, nämä alueet ovat yleensä sekundaareja ja niiden takana on monimutkainen verkosto kielten liikkeitä ajassa ja paikassa. Kielialueet ovat historian ja esihistorian kuluessa voineet kasvaa (ekspansio), supistua (kontraktio) tai siirtyä (translokaatio), ja kielihistoriallinen tutkimus voi antaa tietoa näistä muutoksista.

Keskeinen ja myös suurta yleisöä kiinnostava kysymys kaikkien kielikuntien kohdalla koskee alkukotia (sa. Urheimat) eli sitä muinaista 
kontekstia, josta kielikunta on lähtöisin. Tätä kysymystä lähestytään usein kielikunnan sisäisen rakenteen pohjalta, jolloin oletetaan, että kielikunta on syntynyt siellä, missä se ensimmäisen kerran jakautui eli missä sen syvimmät sisäiset erot sijaitsevat. Apua antaa myös paleolingvistiikkana tunnettu tutkimusala, joka erityisesti kantakielen kulttuuri- ja luontosanastoa analysoimalla tekee johtopäätöksiä sitä vastanneen muinaisen kieliyhteisön kulttuurista ja luonnonympäristöstä. Lisäaineistoa saadaan kielikontaktien ja kielellisten substraattien tutkimuksella, joka paljastaa kielten muinaisia liikkeitä sekä nykyisten kielten alueilla aikaisemmin puhuttujen kielten jälkiä.

Parhaassa tapauksessa kielen varhaisvaiheet voidaan sitoa absoluuttisesti ajoitettaviin arkeologisiin konteksteihin, mutta yleensä kielen ja arkeologian suhde on diffuusi eikä suoria rinnastuksia voida välttämättä koskaan tehdä. Kantakielten ajoituksesta antaakin parhaan osviitan rekonstruoitavan sanaston määrä ja luonne. Mitä vähemmän yhteistä sanastoa on, sitä kauempana ajassa kantakieli todennäköisesti on. Ongelmana on kuitenkin se, että sanasto uudistuu vaihtelevalla nopeudella, eikä tämän vaihtelun yleisiä lainalaisuuksia vielä täysin ymmärretä.

\section{Antropologisen lingvistiikan sovellukset}

Antropologisella lingvistiikalla on monia käytännön sovelluksia, jotka liittyvät erityisesti kielten globaalin uhanalaisuuden ilmiöön. Vaikka kieliä on aina sammunut, maailman kielidiversiteetti ei ole koskaan ollut niin uhattu kuin nykyään. Arviot ilmiön laajuudesta vaihtelevat, mutta varovaistenkin ennustusten mukaan yli puolet ja pessimistisemmän näkemyksen mukaan (Krauss I992) jopa 90 prosenttia maailmassa vielä tällä hetkellä puhutuista kielistä sammuu kuluvan vuosisadan aikana. Tähän uhkaan kielitiede on havahtunut vasta I980-luvulta alkaen. Tyypillistä on, että suuri yleisö ja poliittiset päättäjät suhtautuvat kielten katoon edelleen välinpitämättömästi, samalla kun luonnondiversiteetin katoaminen on jo tiedostettu ongelmaksi - siitä huolimatta, että se 
koskee vain muutamaa prosenttia elävän luonnon moninaisuudesta.

Tilanne on siis hälyttävä ja vaatii nopeita toimia antropologisen lingvistiikan harjoittajilta. Katoavia kieliä on tutkittava, mutta myös niitä puhuvia kieliyhteisöjä on tuettava, ainakin silloin kun yhteisöt itse kokevat kielensä katoamisen ongelmaksi. Ilmiöllä on vahva poliittinen ulottuvuus, sillä ilman valtakoneistojen tukea kielten katoamista on mahdoton pysäyttää. Ongelmana on kuitenkin se, että valtakoneistot - muun muassa kansallisvaltiot ja niiden yhteistyöjärjestöt - ovat perinteisesti juuri ne tahot, jotka ovat edesauttaneet kielten katoamista.

Uhanalaisuuden tiedostaminen. Ensimmäinen askel kielten katoamisen hillitsemiseksi on ilmiön kartoittaminen ja tietoisuuden levittäminen sen seurauksista. I990-luvulta alkaen onkin luotu järjestelmiä ja julkaisukanavia, joihin tietoja uhanalaisista kielistä on voitu syöttää ja joista suuri yleisö voi saada niistä tietoa. Tärkein globaali yritys tällä alalla on ollut Unescon julkaisema uhanalaisten kielten kartasto Atlas of the World's Languages in Danger, josta on ilmestynyt sekä painettuja että verkkoversioita. Tämän hankkeen rinnalle on tullut aluksi Googlen tuella toteutettu uhanalaisten kielten luettelo (Endangered Languages Catalogue eli ElCat), joka pyrkii toimimaan interaktiivisena verkkosivustona.

Yksittäisten kielten uhanalaisuuden astetta on yritetty arvioida monella eri järjestelmällä, joista yksi on The Ethnologue -tietokannan käyttämä EGIDS (Expanded Graded Intergenerational Disruption Scale). Karkeasti maailman kielet voidaan jakaa elinvoimaisiin (engl. viable), uhanalaisiin (engl. endangered), katoaviin (engl. moribund) ja kuolleisiin (engl. extinct), mutta uhanalaisten kielten tila vaihtelee paljon riippuen muun muassa kieliyhteisön absoluuttisesta koosta, ikärakenteesta, stabiliteetista, liikkuvuudesta, kaksikielisyydestä ja virallisesta statuksesta. Yleensä kielten katoamisen takana on kieliyhteisön syrjäytyminen kielten välisessä kilpailussa. On kuitenkin myös entisiä valtakieliä, jotka ovat menettäneet elinvoimansa, kuten Irlannin virallinen kieli iiri.

Usein kysytään, onko uhanalaisten kielten säilyttäminen tarpeellista ja miksi. Vastaus on sama kuin luonnon moninaisuuden osalta: diversiteetti on itseisarvo, joka voi osoittautua ennakoimattomalla tavalla hyödylliseksi. Joka tapauksessa on varmaa, että niin sanottujen luonnonkansojen kulttuurit sisältävät kieleen sidottua tietoa esimerkiksi kasvi- ja 
eläinlajeista, joilla on muun muassa lääketieteellistä käyttöä. Kun kieli katoaa, katoaa myös sen kannattama kulttuuri ja toisin päin, joten uhanalaisten kielten suojelu merkitsee myös kulttuuridiversiteetin suojelua.

Uhanalaisten kielten dokumentointi. Vähin, minkä antropologinen lingvistiikka voi kielellisen diversiteetin säilyttämiseksi tehdä, on dokumentoida katoavat kielet mahdollisimman kattavasti. On usein esitetty, että lingvistin - eikä vain antropologisen lingvistin - koulutukseen tulisi aina sisältyä kenttätyöhön perustuva aikaisemmin tutkimattoman kielen dokumentoiminen. Näin esimerkiksi lingvistisen väitöskirjatyön kohteeksi tulisi aina valita jonkin uhanalaisen kielen kartoitus. Tämän hetken tilanne on pahaenteinen, sillä kieliä katoaa nopeammin kuin niitä ehditään tutkia. Yhtenä syynä on toisen maailmansodan jälkeen alkanut yleisen kielitieteen yksipuolistuminen, joka on vienyt tutkimuksen pois kielidiversiteetistä kohti aivan muita kysymyksenasetteluja. Tilanne on tosin aivan viime aikoina alkanut tältä osin kehittyä parempaan suuntaan. Suomessakin on tehty jo useita väitöskirjoja, joiden kohteena on ollut aikaisemmin dokumentoimaton uhanalainen kieli.

Uhanalaisten kielten kartoitus on mahdollista vain pitkäjänteisen ja systemaattisen kenttätyön avulla, ja kartoituksen tulee tapahtua - kuten aina antropologisessa lingvistiikassa - mahdollisimman yksinkertaisella ja teorioista riippumattomalla tavalla. Näin saatu aineisto palvelee hyvin myös esimerkiksi historiallis-vertailevan kielentutkimuksen ja kielitypologian tarpeita. Ihannetapauksessa uhanalaisen kieliyhteisön kokonaisvaltaiseen tutkimukseen osallistuu tutkijoita myös muilta tieteenaloilta, kuten fyysisestä antropologiasta, folkloristiikasta, uskontotieteestä, historiasta, arkeologiasta ja etnobotaniikasta. Maailmassa on vain harvoja kieliyhteisöjä, jotka on riittävän monipuolisesti kartoitettu.

Kielten revitalisointi. Antropologinen lingvistiikka voi myös konkreettisesti auttaa kieliyhteisöjä ylläpitämään ja elvyttämään kieliään. Kielten elvytys eli revitalisaatio on varsinaisesti vasta i990-luvulta alkaen noussut yhdeksi kielitieteen sovellusalueeksi (Hinton, Huss \& Roche 20I8). Kielen kato tapahtuu yleensä käyttöyhteyksien eli domeenien menetyksen kautta. Kielen elvytys tulee ajankohtaiseksi viimeistään silloin, kun kielen jatkuvuus yhteisössä on katkennut eli kun on ehtinyt kasvaa yksi sukupolvi, joka ei enää hallitse yhteisön omaa alkuperäistä kieltä. Koska 
varsinkin pienten niin sanottujen alkuperäiskansojen kielten käyttöyhteydet ovat hyvin kulttuurisidonnaisia, kielen elvytys vaatii usein myös kulttuurin elvytystä tai ainakin suojelua.

Onnistuneita kielenelvytysprojekteja on maailmassa toistaiseksi vain muutamia: näitä myönteisiä esimerkkejä ovat Uuden-Seelannin maori, Havaijin saarten havaiji sekä Suomen Lapin inarinsaame, joille kaikille on rakennettu uusi puhujasukupolvi. Inarinsaamen elvytystyötä on käsitellyt väitöskirjassaan Annika Pasanen (20I5). Päämenetelminä tässä työssä on käytetty toisaalta niin sanottuja opettaja-oppilasryhmiä (engl. master-apprentice), toisaalta kielipesiä (engl. language nest). Opettajaoppilasryhmissä vanhemman, kieltä hyvin taitavan sukupolven edustajat kehittävät vapaan keskustelun avulla nuoremman, kieltä heikommin taitavan sukupolven kielitaitoa. Kielipesissä taas kieltä täysin taitamaton nuorin sukupolvi osallistuu päiväkotimuotoiseen kielikylpyyn, jossa käytetään yksinomaan elvytettävää kieltä.

Kielenelvytys on mahdollista ainoastaan, jos yhteisöllä on riittävä motivaatio kielen palauttamiseen. Usein riittää, että yhteisössä on muutama aktiivinen yksilö, joiden johdolla projekti voi alkaa. Yleensä tarvitaan kuitenkin myös julkista tukea, sekä rahallista (esimerkiksi kielipesien toiminnan aloittamiseen) että moraalista. Julkisella tuella valtayhteisö, jonka käsissä myös valtakoneistot ovat, voi osoittaa arvostavansa elvytettävää kieltä. Kokemus osoittaa, että kielen elvytys voi toimia ensiaskeleena myös kulttuurin elvytykselle. Yhteisön omanarvontunto kohoaa oman kielen taidon kasvaessa, mikä vähentää sosiaalista syrjäytymistä ja saattaa viime kädessä olla valtayhteisölle taloudellisestikin edullista.

Kirjakielten luominen. Usein kielenelvytysprojekteihin liittyy myös kielen kirjoitetun käytön edistäminen. Useimmat maailman uhanalaisista kielistä ovat vailla kirjoitusperinnettä, mikä tarkoittaa sitä, että niiden puhujat käyttävät kirja- ja sivistyskielinään muita kieliä. Kirjoitetun kielen periaatteiden luominen sopii hyvin lingvistisen antropologian kohteeksi, sillä se edellyttää tutkittavan kielen äännejärjestelmän analyysiä ja sen suhteuttamista käytettävissä oleviin kirjoitusjärjestelmiin, jotka eivät suinkaan aina rajoitu latinalaiseen kirjaimistoon. Tuloksena on parhaassa tapauksessa uuden, kirjallisen domeenin syntyminen uhanalaiselle kielelle. 
Olisi kuitenkin virhe kuvitella, että kirjoitetun kielen luominen sinänsä voisi pelastaa kielen katoamiselta. Erityisen tarpeetonta ja jopa vaarallista on luoda sisäisesti aina varioivalle ja aikaisemmin vain puhuttuna käytetylle kielelle yhtenäinen normatiivinen kirjakieli. Sen sijaan että puhujat kokisivat kirjakielen uudeksi domeeniksi, he saattavat nähdä sen omalle puheelleen vieraana ja keinotekoisena rakennelmana. Parempi onkin, jos kielelle luodaan ainoastaan löyhät oikeinkirjoituksen periaatteet, joita voi tarvittaessa soveltaa esimerkiksi sähköisessä kommunikoinnissa. Kirjallisen kulttuurin luominen hyvin pienen yhteisön kielelle on käytännössä epätarkoituksenmukaista ja resursseja haaskaavaa.

Eettiset kysymykset. Kielten elvyttäminen ja kirjoitusjärjestelmien luominen voidaan selkeästi nähdä antropologisen lingvistiikan "lahjoina" tutkittavia kieliä puhuville yhteisöille. Yleensä yhteisöt ottavat nämä lahjat myönteisesti vastaan, ja ne voidaankin nähdä luonnollisina vastapalveluksina yhteisöille, jotka toimivat tutkimuksen kohteina. On kuitenkin vaikeampi ottaa kantaa siihen, onko myös pelkkä kielten dokumentoiminen lahja puhujayhteisöille. Useinhan kielen dokumentoiminen on tutkijalle meritoivaa toimintaa, jonka kautta voi aueta esimerkiksi tieteellinen ura. Puhujille tutkijan apuna toimiminen voi kuitenkin merkitä vain ylimääräistä vaivaa, josta heille ei välttämättä koidu mitään välitöntä korvausta.

Varsinkin pohjoisamerikkalaisen poliittisen korrektiuden diskurssissa on pienten etnisten ryhmien keskuuteen levitetty ajatusta, että kieli, kuten myös sitä puhuvan yhteisön kulttuuri ja geeniperimä, ovat yhteisön omaisuutta, jota ei tule luovuttaa ulkopuoliseen tutkimuskäyttöön. Tällainen asenne on tutkimukselle haitallinen ja tekee antropologisen lingvistiikan harjoittamisen, kuten muunkin antropologisen tutkimuksen, hankalaksi ja poliittisesti arkaluontoiseksi. On kuitenkin muistettava, että kieli on immateriaalinen ominaisuus, jota ei sellaisenaan voida ottaa pois kieliyhteisöltä, vaikka se dokumentoitaisiin - päinvastoin kielen dokumentoiminen voi auttaa yhteisöä säilyttämään kielensä. Kaikki kielet ovat ihmiskunnan yhteistä omaisuutta, eikä kieliyhteisöillä ole yksinoikeutta omiin kieliinsä.

On silti hyvä miettiä, miten kielenoppaiden työ on parhaiten korvattavissa, sillä kielen akateeminen tutkimus ei välttämättä riitä korvaukseksi 
heidän vaivannäöstään. Parhaassa tapauksessa tutkija tulee siinä määrin tutkimansa kieliyhteisön jäseneksi, että kysymys ei aktuaalistu, mutta usein tutkijan on korrektia huolehtia siitä, että kielenoppaat saavat myös aineellisen korvauksen. Tämä on aina syytä ottaa huomioon dokumentaatioprojektien budjettia suunniteltaessa (kielten dokumentaatioon liittyvistä eettisistä ja käytännöllisistä ongelmista ks. Kielten dokumentointi ja kieliopin kuvaus tk.).

\section{Yhteenveto: antropologisen lingvistiikan toimijoita}

Vaikka alalla on pitkät perinteet, lingvistinen antropologia on organisoituna kansainvälisenä tieteenalana varsin nuori. Alan modernit oppi- ja käsikirjat ovat enimmäkseen englanninkielisiä, tärkeimpinä William Foleyn Anthropological Linguistics (1997) ja Alessandro Durantin Linguistic Anthropology (1997). Esimerkki alan viimeaikaisista sovelluksista etnolingvistiikan nimellä on James W. Underhillin Ethnolinguistic and Cultural Concepts (20I2). Uhanalaisia kieliä käsittelevät esimerkiksi teokset Austin \& Sallabank (20I2) ja Rehg \& Campbell (20I8).

Alan tunnetuin yhdysjärjestö on pohjoisamerikkalainen lingvistisen antropologian seura, Society for Linguistic Anthropology (SAL), joka kuuluu osana Amerikan antropologiseen liittoon, American Anthropological Association. Seura on vuodesta I959 alkaen julkaissut alan aikakauslehteä nimeltä Anthropological Linguistics. Toinen merkittävä toimija on niin ikään pohjoisamerikkalainen kielen esihistorian tutkimuksen seura, Association for the Study of Language in Prehistory (ASLIP), joka vuodesta I995 alkaen on julkaissut aikakauslehteä Mother Tongue. Kenttätyöperinteen kehittäjänä on muistettava myös Summer Institute of Linguistics (SIL), joka järjestää säännöllisesti kielitieteen koulutusta protestanttista lähetystyötä tekeville lingvisteille sekä julkaisee kenttätyöhön perustuvia tutkimustuloksia muun muassa sivustolla nimeltä SIL Forum for Language Fieldwork. 
Alan suomalaista perinnettä edustava Suomalais-Ugrilainen Seura on perustamisestaan (I883) lähtien julkaissut kielitieteellisen kenttätyön tuloksia. Seuran aikakauskirjassa Journal de la Société Finno-Ougrienne ja sen rinnalla ilmestyvissä "Toimituksissa", Mémoires de la Société FinnoOugrienne, on jo I35 vuoden ajan ilmestynyt lukuisien euraasialaisten kielten kieliopillisia ja kielihistoriallisia kuvauksia, joita täydentävät seuran julkaisemat tieteelliset sanakirjat. Seura on myös merkittävällä tavalla osallistunut kielten uhanalaisuutta koskevaan keskusteluun jo paljon ennen kuin aihe nousi kansainvälisen lingvistiikan kohteeksi.

\author{
Aiheesta lisää: \\ Duranti, Alessandro. 1997. Linguistic Anthropology. Cambridge: \\ Cambridge University Press. \\ Foley, William. 1997. Anthropological Linguistics: An Introduction. \\ Malden (MA): Blackwell. \\ Underhill, James W. 2012. Ethnolinguistics and Cultural Concepts: \\ Truth, Love, Hate and War. Cambridge: Cambridge University Press.
}

\title{
KIRJALLISUUS
}

Aikhenvald, Aleksandra Y. \& Mihas, Elena (toim.). 2019. Genders and Classifiers: A CrossLinguistic Typology. Oxford: Oxford University Press.

Austin, Peter \& Sallabank, Julia (toim.). 2012. The Cambridge Handbook of Endangered Languages. Cambridge: Cambridge University Press.

Boas, Franz. 1911-1922. Handbook of American Indian languages. Smithsonian Institution, Bureau of American Ethnology Bulletin 40. Washington: Government Printing Office.

Berlin, Brent \& Kay, Paul. 1969. Basic Color Terms: Their Universality and Evolution. Berkeley: University of California Press.

Bopp, Franz. 1816. Über das Conjugationssystem der Sanskritsprache in Vergleichung mit jenem der griechischen, lateinischen, persischen und germanischen Sprache. Frankfurt am Main: In der Andreäischen Buchhandlung.

Brown, Penelope \& Levinson, Stephen. 1987. Politeness: Some Universals in Language Usage. Cambridge: Cambridge University Press. 
Dixon, R. M. W. 2009. Basic Linguistic Theory, vol. 1-2. Oxford: Oxford University Press.

Duranti, Alessandro. 1997. Linguistic Anthropology. New York (NY): Cambridge University Press.

Foley, William A. 1997. Anthropological Linguistics: An Introduction. Oxford: Wiley Blackwell. Hinton, Leanne, Huss, Leena \& Roche, Gerald (toim.). 2018. The Routledge Handbook of Language Revitalization. New York (NY) \& London: Routledge.

Krauss, Michael. 1992. The world's languages in crisis. Language 68:1, 4-10.

Morgan, Lewis H. 1871. Systems of Consanguinity and Affinity of the Human Family.

Contributions to Knowledge, vol. XVII. Washington: Smithsonian Institution.

Mühlhäusler, Peter. 1996. Linguistic Ecology: Language Change and Linguistic Imperialism in the Pacific Region. London \& New York (NY): Routledge.

Pasanen, Annika. 2015. Kuávsui já peeivičuovâ. 'Sarastus ja päivänvalo'. Inarinsaamen kielen revitalisaatio. Uralica Helsingiensia 9. Helsinki: Helsingin yliopisto \& SuomalaisUgrilainen Seura.

Rehg, Kenneth L. \& Campbell, Lyle (toim.). 2018. The Oxford Handbook of Endangered Languages. Oxford: Oxford University Press.

Sapir, Edward. 1949. Selected Writings in Language, Culture and Personality. Toimittanut David Mandelbaum. Berkeley: University of California Press.

Saussure, Ferdinand de. 2014. Yleisen kielitieteen kurssi. [Cours de linguistique générale.] Tampere: Vastapaino.

Underhill, James W. 2012. Ethnolinguistics and Cultural Concepts: Truth, Love, Hate and War. Cambridge: Cambridge University Press.

Whorf, Benjamin. L. 1956. Language, Thought, and Reality: Selected Writings of Benajmin Lee Whorf. Toimittanut John B. Carroll. Cambridge (MA): MIT Press.

\section{ERÄITÄ VERKKO-OSOITTEITA}

Association for the Study of Language in Prehistory: http://aslip.org/MT/MT1.htm. Endangered Languages Catalogue: http://ling.hawaii.edu/research-current/projects/elcat/. SIL International: https://www.sil.org.

Society for Linguistic Anthropology: http://linguisticanthropology.org.

Suomalais-Ugrilainen Seura: https://www.sgr.fi.

Unescon Atlas of the World's Languages in Danger: http://www.unesco.org/languagesatlas/. 